\title{
Selenium Speciation in Waste Materials From an Exhausted Iberian Pyrite Belt Mine
}

\author{
Maria-Ondina Figueiredo ${ }^{1,2}$, Teresa P. Silva ${ }^{2}$, João P. Veiga ${ }^{1}$, Maria-João Batista ${ }^{2}$, Eduardo Salas-Colera ${ }^{3,4}$ \& \\ Daniel P. de Oliveira ${ }^{2}$ \\ ${ }^{1}$ CENIMAT/I3N, Faculty of Sciences and Technology, New University of Lisbon, Caparica, Portugal \\ ${ }^{2}$ Unity of Mineral Resources \& Geophysics, Nat. Lab. Energy \& Geology (LNEG), Amadora, Portugal \\ ${ }^{3}$ SpLine, Spanish CRG Beamline, European Synchrotron Radiation Facility (ESRF), Grenoble, France \\ ${ }^{4}$ Instituto de Ciencia de Materiales, Consejo Sup. Investigaciones Cientificas, (ICMM/CSIC), Madrid, Spain \\ Correspondence: Maria-Ondina Figueiredo, Unity of Mineral Resources and Geophysics, National Laboratory \\ of Energy and Geology (LNEG), Apartado 7586, 2610-999 Amadora, Portugal. Tel: 351-210-924-600. E-mail: \\ ondina.figueiredo@lneg.pt
}

Received: June 29, 2014 Accepted: August 12, 2014 Online Published: August 14, 2014

doi:10.5539/jmsr.v3n4p22

URL: http://dx.doi.org/10.5539/jmsr.v3n4p22

\begin{abstract}
Selenium is an essential nutrient for humans, animals and microorganisms, but it becomes toxic at concentrations slightly above the nutritional levels. This naturally occurring trace element can be released to the environment from various anthropogenic sources such as mining, agricultural, petrochemical and industrial processes and its toxicity is developed along a complex cycle involving adsorption by soil components and subsequent accumulation by plants. In the environment, selenium can occur in several oxidation states ranging from selenide $\left(\mathrm{Se}^{\overline{ }}\right)$ to elemental selenium $\left(\mathrm{Se}^{0}\right)$, selenite $\left(\mathrm{Se}^{4+}\right)$ and selenate $\left(\mathrm{Se}^{6+}\right)$. Selenium contents above $900 \mathrm{ppm}$ were recently assigned in mine wastes from the sulphur factory at the São Domingos exhausted pyrite mine exploited in the Iberian Pyrite Belt (south Portugal) since Roman times until 1966. Aiming at a sustainable remediation of this mining site, an X-ray absorption spectroscopy study using synchrotron radiation, combined with X-ray diffraction, was undertaken to clarify the speciation state of selenium and the nature of Se-carrier phase(s). The results show that selenium does not significantly replace sulphur under the form of selenate in the dominant sulphate phases and occasionally remains as a substituting selenide anion in debris of the original sulphides present in the mine waste materials.
\end{abstract}

Keywords: Selenium, mining wastes, Iberian Pyrite Belt, X-ray absorption spectroscopy, XANES

\section{Introduction}

Mine wastes configure nowadays two quite opposite interests since they represent simultaneously an environ-mental concern due to the presence of hazardous metals and other toxic elements, plus a potential mineral resource when they are the object of a sustainable recovery of economically valuable metals.

The increased demand of some scarce metals observed in the last decade has intensified the search for their recuperation from mine wastes and residual exploitation materials, thus enhancing the need for a full comprehension of the way these metals are incorporated. A successful accomplishment of this task requires the use of advanced X-ray absorption methodologies, as exemplified by a recent study on mining debris of the exhausted centennial Iberian Pyrite Belt (IPB) mine of São Domingos in southeast Portugal (Alvarez-Valero et al., 2008) to assess the binding state of a very scarce metal, rhenium (Figueiredo et al., 2014). The actual interest in exploring mining residues plus industrial wastes derived from former ore deposits processing plants was clearly highlighted in the context of the recently concluded EU research project, ProMine (Nano-particle products from new mineral resources in Europe, FP7-NMP-2008-LARGE-2, 228559).

Selenium is known for its toxicity (Lenz \& Lens, 2009), developed along a complex cycle involving adsorption by soil components clays and iron-rich particulate minerals (Hayes et al., 1987; Peak \& Sparks, 2002; Scheinost \& Charlet, 2003) and subsequent accumulation by plants (Ellis \& Salt, 2003); as a component of radioactive wastes, it also configures a concern through the isotope ${ }^{79} \mathrm{Se}$ (Ashworth \& Shaw, 2006). Aside these apprehensions, 
selenium may contribute in a positive way to moderate the toxicity of hazardous metals like mercury (Sørmo et al., 2011), being simultaneously recognized as an essential nutrient for animals, humans and microorganisms.

Resembling sulphur in many of its properties, small concentrations of Se commonly replace $\mathrm{S}$ in sulphide ore minerals and natural sulphates. In the ground state, it has an electronic configuration [Ar] $3 d^{10} 4 s^{2} 4 p^{4}$, and occurs as an element $\left(\mathrm{Se}^{0}\right)$ under several allotropic forms, either amorphous (vitreous black selenium) or crystalline red-coloured monoclinic $\alpha, \beta$ and $\gamma$ forms, with $\mathrm{Se}^{8}$ rings similar to $\mathrm{S}^{8}$, and a metallic hexagonal gray form with helical polymeric chains (Minaev, Timoshenkov \& Kalugin, 2005). In the natural environment, various oxidation states are common beyond elemental selenium: reduced, selenide $\left(\mathrm{Se}^{-}\right)$plus $\left[(\mathrm{Se}-\mathrm{Se})^{\circ}\right]$ species forming diselenide $\left(\mathrm{Se}_{2}{ }^{\prime}\right)$ anions; and oxidized forms - $\left(\mathrm{Se}^{4+}\right)$ and $\left(\mathrm{Se}^{6+}\right)$ cations combined with oxygen to form divalent anions, selenite $\left[\mathrm{Se}^{\pi} \mathrm{O}_{3}\right]$ and selenate $\left[\mathrm{Se}^{t} \mathrm{O}_{4}\right]$, where $\pi$ stands for pyramidal and $\underline{t}$ for tetrahedral coordination. The most soluble Se species is the selenate, readily taken up by plants and leached through the soil profile, and all the quoted species can be identified through X-ray absorption spectroscopy in mine waste materials (Ryser et al., 2005).

Selenium was recently quantified in mining debris and waste materials from the São Domingos mine, exploited since Antiquity until 1966, and determined contents attained 900 ppm (Batista et al. 2011), thus rising a special interest about the speciation state(s) of selenium in so heterogeneous materials. In fact, Se-carrier phase(s) could be either oxygen-rich compounds resulting from the ore processing at the old sulphur factory or remains of former chalcogenide ore minerals. An X-ray absorption spectroscopy study using synchrotron radiation, combined with a phase characterization of the irradiated material by X- ray diffraction, was carried out to clarify the speciation of selenium.

\section{Materials and Methods}

\subsection{Studied Materials}

Wastes and debris from the exhausted São Domingos mine, deposited near the old sulphur factory at Achada do Gamo, were drilled within the frame of the already mentioned ProMine EU-FP7 research project. Following a laboratory qualitative assay to certify the presence of selenium by wavelength dispersive X-ray fluorescence (WDS-XRF), three samples were selected for the spectroscopic study (references 3-3, 3-4 and 3-5, Figure 1).

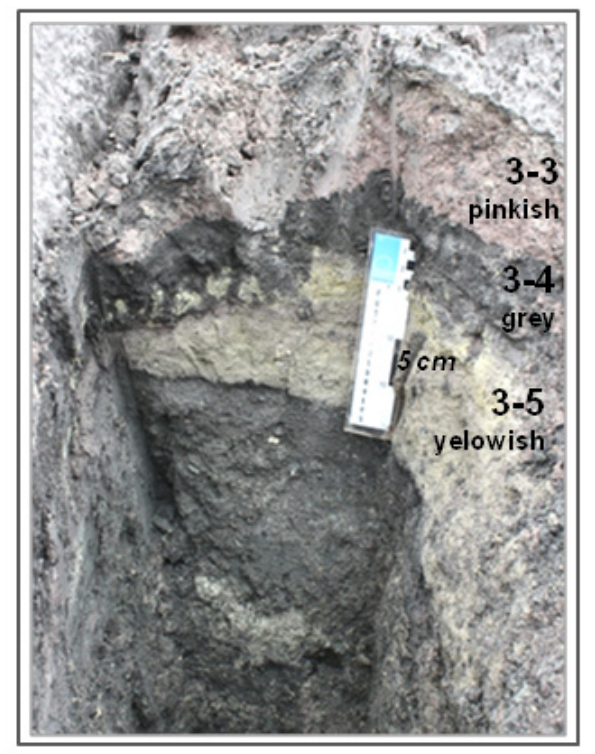

Figure 1. Samples from the profile of milled pyrite ore and processed materials drilled at Achada do Gamo in the São Domingos mine area

The results of chemical analysis of the sampled waste materials are summarized in Table 1. Worth remarking is the colour variation of studied samples, ranging from yellowish (3-5) through light gray (3-4) to faintly-rose (3-3) as a result of the variable mineralogical constitution, coupled with the redox state of iron - an element well represented in the drilled materials. 
Table 1. Concentrations of some significant elements in the waste samples taken from São Domingos mine (ACTLABS analyses, ProMine Project)

\begin{tabular}{|c|c|c|c|c|c|c|c|c|}
\hline Analyte symbol & $\mathrm{Fe}$ & $\mathrm{Ca}$ & $\mathrm{S}$ & $\mathrm{Cu}$ & $\mathrm{Zn}$ & As & $\mathrm{Sb}$ & $\mathrm{Se}$ \\
\hline Unit symbol & $\%$ & $\%$ & $\%$ & ppm & ppm & ppm & ppm & ppm \\
\hline Detection limit & - & 0.01 & 0.01 & 1 & 1 & - & - & - \\
\hline Analysis method & INAA & TD-ICP & TD-ICP & TD-ICP & TD-ICP & INAA & INAA & INAA \\
\hline Sample $3-5$ & 9.45 & 2.52 & 6.0 & 1400 & 2150 & 17100 & 3560 & 507 \\
\hline Sample 3-4 & 2.76 & 2.64 & 9.48 & 297 & 190 & 14400 & 7780 & 738 \\
\hline Sample 3-3 & 2.81 & 1.66 & 8.5 & 190 & 395 & 7200 & 5700 & 937 \\
\hline
\end{tabular}

Analytical methods: INAA, Instrumental Neutron Activation Analysis; TD-ICP, Total Digestion Inductively Coupled Plasma Mass Spectrometry. The concentrations of $\mathrm{Pb}$, Bi and $\mathrm{Sn}$ (as accessed by ICP-MS) are respectively above 5000, 2000 and 200 ppm (Batista et al., 2011) in the studied samples.

Museum specimens of paraguanajuatite/guanajuatite $\left[\mathrm{Bi}_{2}(\mathrm{Se}, \mathrm{S})_{3}\right]$ from Guanajuato (Mexico) and of Se-rich galena $[\mathrm{Pb}(\mathrm{S}, \mathrm{Se})]$ from Derbyshire/England were used as model minerals to collect standard XANES spectra of selenium anions, either isolated as selenide ions $\left[\mathrm{Se}^{*}\right]$ in clausthalite, PbSe (Coleman, 1959) or displaying Se-Se interaction/binding in orthorhombic guanajuatite, isostructural with stibnite, $\mathrm{Sb}_{2} \mathrm{~S}_{3}$ (Bayliss \& Nowacki, 1972) and in trigonal paraguanajuatite (Earley, 1950).

The commercial products taken from Sigma-Aldrich (checked by X-ray diffraction in the laboratory) were used as model Se-O compounds configuring various formal valences and geometrical coordination environments of selenium cations: selenite in $\mathrm{Na}_{2} \mathrm{SeO}_{3}$ with $\mathrm{Se}^{4+}$ cations in pyramidal coordination by oxygen anions (Wickleder, 2002) and selenate in $\mathrm{Na}_{2} \mathrm{SeO}_{4}$ with $\mathrm{Se}^{6+}$ cations assuming a tetrahedral coordination (Fukami \& Chen, 2003).

\subsection{Methods and Techniques}

The speciation study of selenium was carried out at the European Synchrotron Radiation Facility (ESRF, in Grenoble/France) by applying X-ray absorption spectroscopy at beamline BM-25A, SpLine (Rubio-Zuarzo \& Castro, 2009).

$\mathrm{X}$-ray absorption near-edge spectra (XANES) were collected at the Se $K$-edge (nominally at $12658 \mathrm{eV}$ for elemental selenium (Ravel \& Newville, 2005) in fluorescence yield (FY) mode with an energy resolution of $\Delta \mathrm{E} / \mathrm{E}=1.5 \times 10^{-4}$ using a 13 -element $\mathrm{Si}(\mathrm{Li})$ solid-state detector and a $\mathrm{Si}(111)$ monochromator, by irradiating powdered samples enclosed between two Kapton foils or, in the case of galena, a mineral fragment. Pure zinc and zirconium metal foils were irradiated in transmission mode for energy calibration purposes.

Using the instrumental facilities available at the beamline, the phase constitution of irradiated mine waste materials was characterized by high-resolution powder diffraction (HRPD) performed with a fixed wavelength of $0.825 \AA$. HRPD patterns were collected from $2^{\circ}$ to $33^{\circ}$ in a continuous $2 \theta$-scanning mode by irradiating powdered samples placed inside a $0.8 \mathrm{~mm}$ diameter capillary tube that was rotated during the exposure to synchrotron radiation.

The chemical characterization of studied mine wastes at the irradiated points was performed by X-ray fluorescence spectrometry and the energy dispersive spectra (EDS-XRF) were evaluated using the PyMca program (Solé et al., 2007).

\section{Results and Discussion}

\subsection{Chemistry and Phase Composition of Studied Mine Waste Samples}

Sulphates are the dominant phases in the mine waste samples, according to the collected HRPD patterns (Figure 2, with $2 \theta^{\circ}$ values converted for the wavelength of $\mathrm{Cu} K \alpha$ radiation currently used in laboratory X-ray diffraction experiments). 


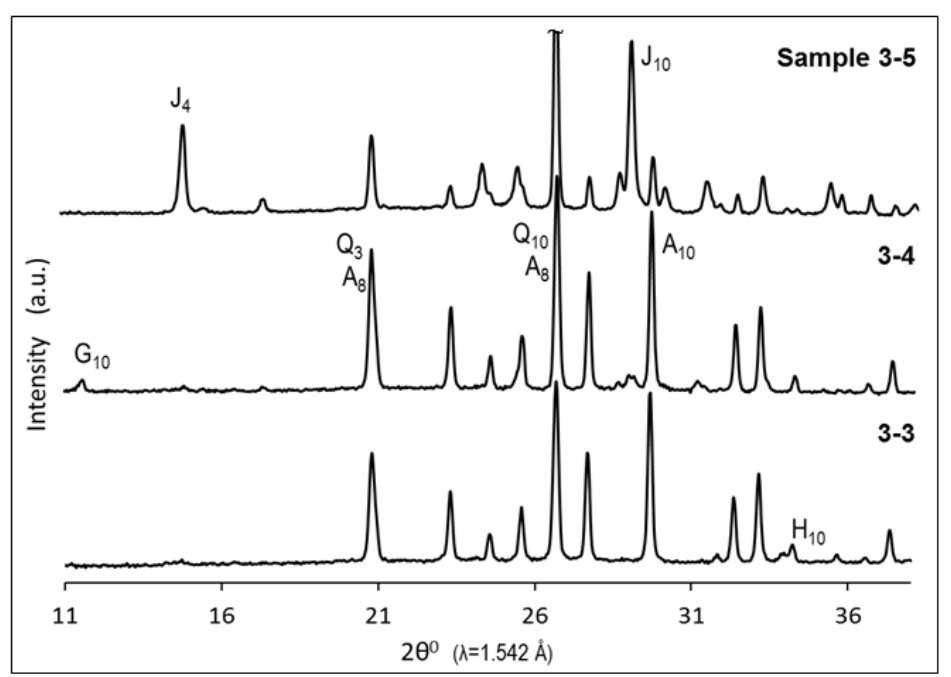

Figure 2. X-ray diffraction patterns of powdered mine waste samples

A - anglesite, $\mathrm{PbSO}_{4}$ (JCPDF card 5-577); $\mathrm{G}$ - gypsum, $\mathrm{CaSO}_{4} \cdot 2 \mathrm{H}_{2} \mathrm{O}$ (6-046); $\mathrm{H}$ - hematite, $\alpha-\mathrm{Fe}_{2} \mathrm{O}_{3}$ (13-534); $\mathrm{J}$ - jarosite, $\mathrm{KFe}_{3}(\mathrm{OH})_{6}\left(\mathrm{SO}_{4}\right)_{2}(22-827) ; \mathrm{Q}$ - quartz, $\alpha-\mathrm{SiO}_{2}(5-490)$.

The phase constitution varies between a dominant ferric sulphate - jarosite, $\mathrm{KFe}_{3}(\mathrm{OH})_{6}\left(\mathrm{SO}_{4}\right)_{2}-$ with minor lead sulphate - anglesite, $\mathrm{PbSO}_{4}$ - in sample 3-5, and major anglesite plus minor jarosite in samples 3-3 and 3-4, along with minor hematite $\left(\alpha-\mathrm{Fe}_{2} \mathrm{O}_{3}\right)$; gypsum $\left(\mathrm{CaSO}_{4} \cdot 2 \mathrm{H}_{2} \mathrm{O}\right)$, was assigned in sample 3-4, responding to the slightly higher contents of calcium and sulphur (Table 1). Actual results clearly conform to the chemical analysis of mine waste materials (Batista et al., 2011) and to the variable colourings displayed by the studied samples.

The high lead and bismuth contents of São Domingos mine wastes are evident from the collected EDS-XRF spectra (Figure 3), that allow for a rough visual evaluation of the relative contents of other metals (iron, copper, zinc) and non-metallic elements (selenium and arsenic), despite the low concentrations listed in Table 1.

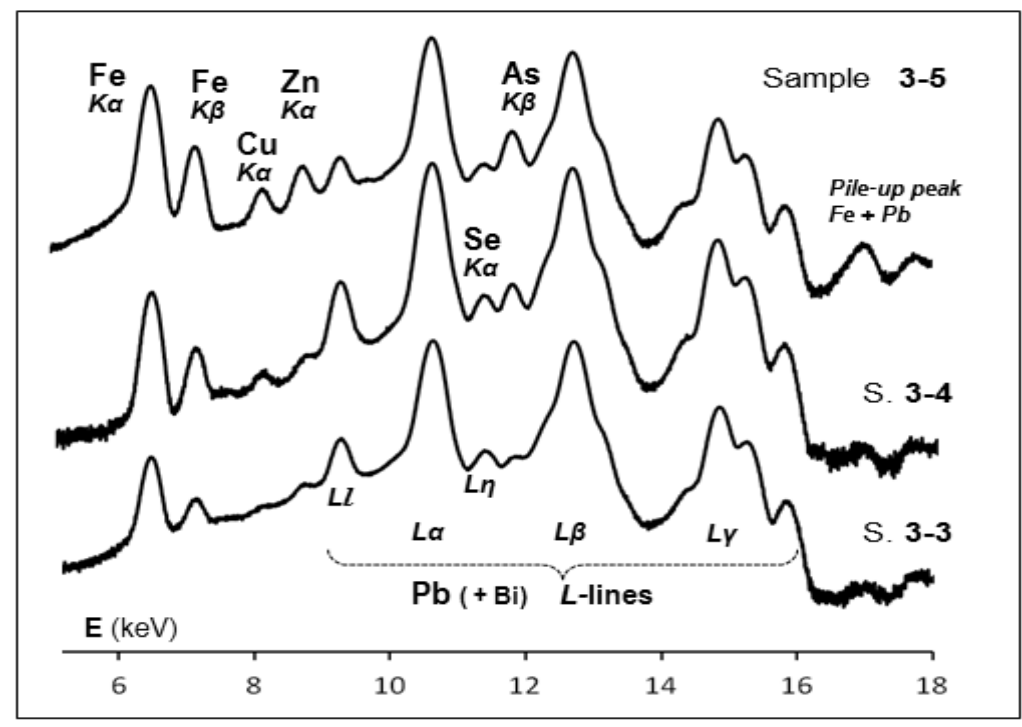

Figure 3. Energy dispersive X-ray fluorescence (EDS-XRF) spectra obtained for the mine waste materials irradiated to collect the Se $K$-edge XANES spectra 
In order to confirm the presence of selenium in the irradiated fragment of well crystallized galena, an EDS-XRF spectrum was collected for comparison with the corresponding spectrum obtained from the Se-richest mine waste sample (Figure 4).

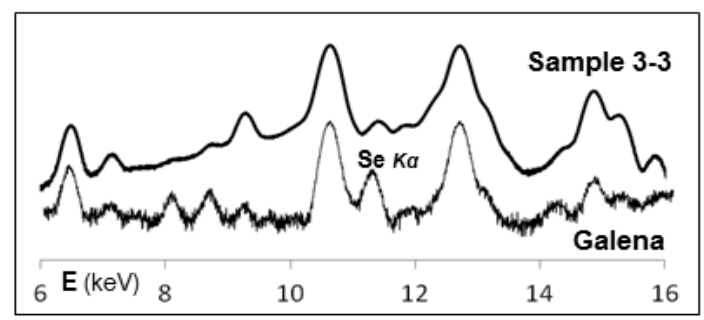

Figure 4. EDS-XRF spectra of the Se-richest mine waste sample and galena fragment

Following the XANES experiment, a complementary laboratorial study of this galena fragment was carried out by $\mathrm{X}$-ray diffraction using a Bragg-Brentano powder diffractometer equipped with a large anode copper tube to check the phases present. The surface of the crystalline fragment was directly irradiated and a continuous scanning was performed in the angular $2 \theta^{\circ}$ region suitable to identify the possible surface oxidation phase(s) - that is, abridging the $h \mathrm{kl}$ reflection of galena with highest intensity (practically coinciding with the highest intensity diffraction peak of lead sulphate, $\mathrm{PbSO}_{4}$ ), and two weak reflections stemming from vestigial phases, either original - lead selenide, the mineral clausthalite known to form an extensive solid solution with the isostructural lead sulphide (Coleman, $1959)$ - or oxidized. Figure 5 reproduces the obtained XRD pattern for the $2 \theta^{\circ}$ interval $28^{\circ}-33^{\circ}$ where, along with non-oxidized vestigial $\mathrm{PbSe}$, the registered diffraction peaks clearly denote the presence of a possible lead sulphite (or mixed lead sulphite-selenite), Indeed, $\mathrm{PbSO}_{3}$ and $\mathrm{PbSeO}_{3}$ are isostructural and display a monoclinic crystal structure-type (Fisher, 1985; Pertlik \& Zemann, 1985), occurring in nature, respectively as the minerals scotlandite and molybdomenite.

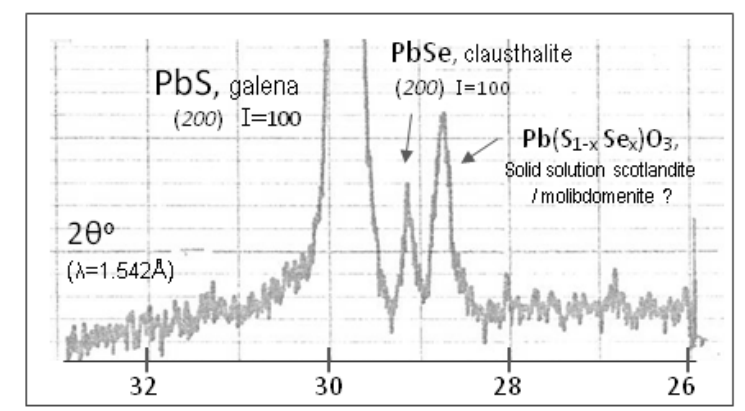

Figure 5. Results from a laboratorial X-ray diffraction study of the surface mineralogical constitution of the studied galena fragment

\subsection{X-Ray Absorption Spectroscopy Study}

Se $K$-edge X-ray absorption spectra collected from the mine waste materials show a distinctive lay-out for sample (3-5) comparatively to the other two samples. Selenium is extensively oxidized in the first case where jarosite is the dominant constituting sulphate phase (see Figure 2), while the occurrence of reduced selenium is still significant in the other two samples.

In view of clearly perceptible differences in the degree of selenium oxidation, the Se $K$-edge XANES spectra of the three mine waste materials are separately compared with the spectra obtained for $\mathrm{Se}-\mathrm{O}$ model compounds (a selenite, $\mathrm{Na}_{2} \mathrm{SeO}_{3}$, and a selenate, $\mathrm{Na}_{2} \mathrm{SeO}_{4}$, in the case of sample 3-5, Figure 6) and for the model selenide minerals (guanajuatite/paraguanajuatite, $\mathrm{Bi}_{2}\left(\mathrm{Se}_{1-\mathrm{y}} \mathrm{S}_{\mathrm{y}}\right)_{3}$, and galena, $\mathrm{Pb}\left(\mathrm{S}_{1-\mathrm{x}} \mathrm{Se}_{\mathrm{x}}\right)$, in the case of the other two samples, Figure 7). 


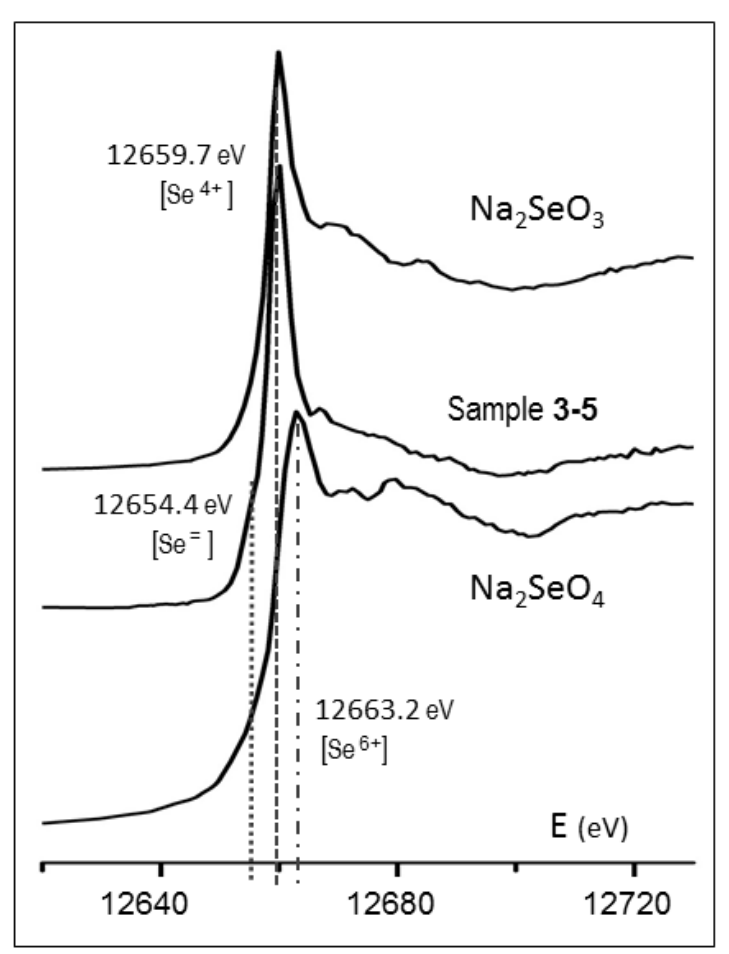

Figure 6. Se $K$-edge XANES spectrum collected from sample 3-5 compared to the spectra obtained for selenite and selenate model compounds showing that selenium dominant redox state is $4+$ in the mine waste material, despite the perceptible occurrence of selenide anions

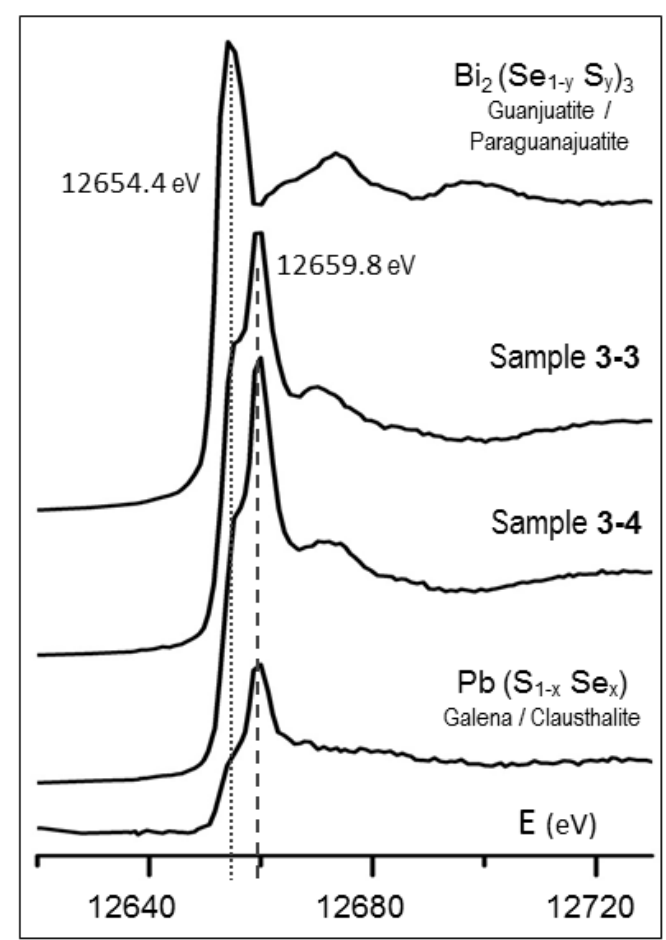

Figure 7. Se K-edge XANES spectra of samples 3-3 and 3-4 compared to the spectra obtained for the selenide model minerals, showing that $\mathrm{Se}^{=}$anions are quite well represented 
The energy of the strong absorption maximum - the so-called white line - was highlighted along with other spectral details to allow for an easy comparison of collected Se $K$-edge XANES spectra. This white line is due to the dipole-allowed $1 s \rightarrow 4 p$ electron transition and its intensity rises with the increase of $4 p$ electron vacancies. As the outer valence electrons are removed and the redox state of selenium increases, the absorption edge energy is therefore expected to shift towards higher values as a result of the decrease in shielding of the core $1 s$ electrons.

Accordingly, the $K$-edge energy of selenium shifts up to almost $10 \mathrm{eV}$ towards higher values with increasing oxidation state, from selenide to selenate (Christensen, Cutler \& Christensen, 2004). Repeatedly quoted values of the white line maximum are $12653.5 \mathrm{eV}$ for $\mathrm{Se}{ }^{=}, 12658.0 \mathrm{eV}$ for Se${ }^{4+}, 12661.5 \mathrm{eV}$ for Se${ }^{6+}$ (Pickering, Brown \& Tokunaga, 1995; Ryser et al., 2006; Scheinhost et al., 2008; Kavshnina et al., 2009; Wiramanaden, Liber \& Pickering, 2010). The result is in good agreement with the sequence of experimental values obtained for the studied mining waste materials (Figures 6 and 7).

\section{Conclusions}

The absence of selenate oxyanions $\left[\mathrm{SeO}_{4}\right]=$ in the studied São Domingos mine waste samples was proven through the analysis of Se $K$-edge X-ray absorption near-edge spectra by comparing with XANES data collected from sodium selenite and selenate model compounds.

This general conclusion calls for further comments taking into account that the mining waste materials are dominated by iron and lead sulphates (respectively, jarosite and anglesite). As already mentioned, selenium resembles sulphur in many of its properties and Se frequently replaces $\mathrm{S}$ in sulphide ore minerals and natural sulphates. Despite the occurrence of the lead double sulphate-selenate mineral olsacherite, $\mathrm{Pb}_{2}\left(\mathrm{SO}_{4}\right)\left(\mathrm{SeO}_{4}\right)$ (Hurlbut \& Aristarain, 1969), the diadochic replacement of S by Se is not significant in anglesite, the same holding for jarosite. Selenate analogs of potassium and sodium jarosites have been synthesized thirty years ago (Dutrizac, Dinardo \& Kalman, 1981), being then remarked that they evolve at lower temperatures than the corresponding sulphates. The thermal behaviour of the synthetics may explain the nonappearance of selenium in the highest oxidation state $\left(\mathrm{Se}^{6+}\right)$, along with an expressive representation of less oxidized selenite ions $\left[\mathrm{SeO}_{3}\right]^{=}$in the studied waste materials of São Domingos IPB old mine.

\section{Acknowledgements}

EU financial support to perform the X-ray absorption experiment EV-13 at the ESRF is acknowledged. Authors affiliated to CENIMAT/I3N acknowledge the support of the Portuguese Funding Agency for Science, Research \&Technology (FCT-MES) through the Strategic Project LA25-2013-2014 (ref. PEst-C/CTM/LA0025/2013-14).

\section{References}

Álvarez-Valero, A. M., Pérez-López, R., Matos, J., Capitán, M. A., Nieto, J. M., Saéz, R., ... Caraballo, M. (2008). Potential environmental impact at S. Domingos mining district (Iberian Pyrite Belt, SW Iberian Peninsula): evidence from a chemical and mineralogical characterization. Environmental Geology, 55, 1797-1809. http://dx.doi.org/10.1007/s00254-007-1131-x

Ashworth, D. J., \& Shaw, G. (2006). Soil migration, plant uptake and volatilisation of radio-selenium from a contaminated water table. Science of the Total Environment, 370, 506-514. http://dx.doi.org/10.1016/j. scitotenv.2006.07.010

Batista, M. J., Matos, J. X., Figueiredo, M. O., de Oliveira, D., Silva, T., Santana, H., \& Quental, L. (2011). Fingerprints for mining products and wastes of the S. Domingos, Aljustrel and Neves-Corvo mines - a sustainable perspective. VIII Iberian Congress of Geochemistry, Castelo-Branco/Portugal, September 21-28. Extended Abstact, 6 pp. Retrieved from http://repositorio.lneg.pt/bitstream/10400.9/1450/1/34970.pdf

Bayliss, P., \& Nowacki, W. (1972) Refinement of the crystal structure of stibnite, $\mathrm{Sb}_{2} \mathrm{~S}_{3}$. Zeitschrift für Kristallographie, 135, 308-315. http://dx.doi.org/10.1524/zkri.1972.135.3-4.308

Christensen, C. R., Cutler, J. N., \& Christensen, D. A. (2004). Using X-ray absorption near edge structures (XANES) spectroscopy to determine selenium oxidation states in animal mineral supplements and feeds. Canadian Journal of Animal Science, 84, 171-175. http://dx.doi.org/10.4141/A03-099

Coleman, R. G. (1959). The natural occurrence of galena-clausthalite solid solution series. American Mineralogist, 44, 166-175.

Dutrizac, J. E., Dinardo, O., \& Kalman, S. (1981). Selenate analogs of jarosite-type compounds. Hydrometallurgy, 6, 327-337. http://dx.doi.org/10.1016/0304-386X(81)90049-9

Earley, J. W. (1950). Description and synthesis of the selenide minerals. American Mineralogist, 35, 337-364. 
Ellis, D. R., \& Salt, D. E. (2003). Plants, selenium and human health. Current Opinion in Plant Biology, 6, 273-279. http://dx.doi.org/10.1016/S1369-5266(03)00030-X

Figueiredo, M. O., Silva, T. P., Veiga, J. P., de Oliveira, D., \& Batista, M. J. (2014). Towards the recovery of by-product metals from mine wastes: an X-ray absorption spectroscopy study on the binding state of rhenium in debris from a centennial Iberian Pyrite Belt mine. Journal of Minerals and Materials Characterization \& Engineering, 2, 135-143. http://dx.doi.org/10.4236/jmmce.2014.22018

Fisher, R. (1972). Die Kristallstruktur von Molybdomenit, $\mathrm{PbSeO}_{3}$. Tschermaks Mineralogische und Petrographische Mitteilungen, 17, 196-207. http://dx.doi.org/10.1007/BF01085993

Fukami, T., \& Chen, R. H. (2003). Refinement of Crystal Structure of $\mathrm{Na}_{2} \mathrm{SeO}_{4}$ at Room Temperature. Journal of the Physical Society of Japan, 72, 3299-3300. http://dx.doi.org/10.1143/JPSJ.72.3299

Hayes, K. F., Roe, A. L., Brown, G. E., Hodgson, K. O., Leckie, J. O., \& Parks, G. A. (1987). In-situ X-ray absorption study of surface complexes: selenium oxy-anions on $\alpha-\mathrm{FeOOH}$. Science, 238, 783-786. http://dx.doi.org/10.1126/science.238.4828.783

Hurlbut, C. S. Jr., \& Aristarain, L. F. (1969) Olsacherite, $\mathrm{Pb}_{2}\left(\mathrm{SO}_{4}\right)\left(\mathrm{SeO}_{4}\right)$, a new mineral from Bolivia. American Mineralogist, 54, 1519-1527.

Kvashnina, K. O., Butorin, S. M., Cui, D., Vegelius, J., Puranen, A., Gens, R., \& Glatze, P. (2009). Electron transfer during selenium reduction by iron surfaces in aqueous solution: high resolution X-ray absorption study. XAFS14, Journal of Physics: Conference Series, 190, 012191. http://dx.doi.org/10.1088/1742-6596/1 90/1/012191

Lenz, M., \& Lens, P. N. L. (2009). The essential toxin: the changing perception of selenium in environmental sciences. Science of the Total Environment, 407, 3620-3633. http://dx.doi.org/10.1016/j.scitotenv. 2008.07 .056

Minaev, V. S., Timoshenkov, S. P., \& Kalugin, V. V. (2005). Structural and phase transformations in condensed selenium. Journal of Optoelectronic Advanced Materials, 7, 1717-1741.

Peak, D., \& Sparks, D. L. (2005). Mechanisms of selenate adsorption on iron oxides and hydroxides. Environmental Science \& Technology, 36, 1460-1466. http://dx.doi.org/10.1021/es0156643

Pertlik, F., \& Zemann, J. (1985). The crystal structure of Scotlandite, $\mathrm{PbSO}_{3}$. Tschermaks Mineralogische und Petrographische Mitteilungen, 34, 289-295. http://dx.doi.org/10.1007/BF01082968

Pickering, I. J., Brown, G. E., \& Tokunaga, T. K. (1995). Quantitative speciation of selenium in soils using X-ray absorption spectroscopy. Environmental Science \& Technology, 29, 2456-2459. http://dx.doi.org/10.1021/e s00009a043

Rubio-Zuazo, J., \& Castro, G. R. (2009). SpLine: Spanish BM25 CRG X-Ray beamline at the European Synchrotron Radiation Facility. Sociedad Española de Mineralogia, Seminar on Synchrotron Radiation in Mineralogy, 6, 89-108.

Ryser, A. L., Strawn, D. G., Marcus, M. A., Fakra, S., Johnson-Maynard, J. L., \& Möller, G. (2006). Microscopically focused synchrotron X-ray investigation of selenium speciation in soils developing on reclaimed mine lands. Environmental Science \& Technology, 40, 462-467. http://dx.doi.org/10.1021/es0 $51674 \mathrm{i}$

Ryser, A. L., Strawn, D. G., Marcus, M. A., Johnson-Maynard, J. L., Gunter, M. E., \& Möller, G. (2005). Micro-spectroscopic investigation of selenium-bearing minerals from the Western US Phosphate Resource Area. Geochemical Transactions, 6, 1-11. http://dx.doi.org/10.1186/1467-4866-6-1

Scheinost, A. C., \& Charlet, L. (2008). Selenite reduction by mackinawite, magnetite and siderite: XAS characterization of nanosized redox products. Environmental Science \& Technology, 42, 1984-1989. http://dx.doi.org/10.1021/es071573f

Solé, V. A., Papillon, E., Cotte, M., Walter, Ph., \& Susini, J. A. (2007). Multiplatform code for the analysis of energy dispersive X-ray fluorescence spectra. Spectrochimica Acta B, 62, 63-68. http://dx.doi.org/10.1016/j. sab.2006.12.002

Sørmo, E. G., Ciesielski, T. M., Øverjordet, I. B., Lierhagen, S., Eggen, G. S., Berg, T., \& Jenssen, B. M. (2011). Selenium moderates mercury toxicity in free-ranging freshwater fish. Environmental Science \& Technology, 45, 6561-6566. http://dx.doi.org/10.1021/es200478b 
Wickleder, M. S. (2002). Sodium selenite, $\mathrm{Na}_{2} \mathrm{SeO}_{3}$. Acta Crystallographica E, 58, i103-i104. http://dx.doi.org/10.1107/S1 600536802019384

Wiramanaden, C. I. E., Liber, K., \& Pickering, I. J. (2010). Selenium speciation in whole sediment using X-ray absorption spectroscopy and micro X-ray fluorescence imaging. Environmental Science \& Technology, 44, 5389-5394. http://dx.doi.org/10.1021/es100822z

\section{Copyrights}

Copyright for this article is retained by the author(s), with first publication rights granted to the journal.

This is an open-access article distributed under the terms and conditions of the Creative Commons Attribution license (http://creativecommons.org/licenses/by/3.0/). 